\title{
Claiming Space: An Autoethnographic Study of Indigenous Graduate Students Engaged in Language Reclamation
}

\author{
Kari A. B. Chew \\ University of Arizona \\ U.S.A. \\ Nitana Hicks Greendeer \\ Boston College \\ U.S.A. \\ Caitlin Keliiaa \\ University of California, Berkeley \\ U.S.A.
}

ABSTRACT: This article explores the critical role of an emerging generation of Indigenous scholars and activists in ensuring the continuity of their endangered heritage languages. Using collaborative autoethnography as a research method, the authors present personal accounts of their pursuit of language reclamation through graduate degree programs. These accounts speak to the importance of access to Indigenous languages and the necessity of space at universities to engage in language reclamation. The authors view higher education as a toolthough one that must be improved-to support Indigenous language reclamation efforts.

KEYWORDS: Indigenous languages, language reclamation, language revitalization, higher education, collaborative autoethnography

Literature Review
Indigenous Research and Collaborative Autoethnography
Kari
Nitana
Katie
Discussion
Conclusions
Notes
References
Author Contact

Chokma, saholhchifoat Kari. Chikashsha saya.

University of Arizona holisso aapisali amanompa' ithana sabannahootokoot.

Hello, my name is Kari. I am a member of the Chickasaw Nation.

I study at the University of Arizona because I want to know my language. 


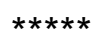

Nutus8ees Nitana kah numâseepeeee wôpanâm.

Nukatwahtamup Linguistics ut MITut, kah wôk Curriculum kah Instruction ut Boston Collegeut. Nutanuhkôs8wânuhshâw Wôpanâak Language Reclamation

Projectah kah nutanunôsayumunât katnuhtôhtâôkanees wuchee Wôpanâôt8âokanee pâhshaneekamuq.

My name is Nitana and I am Mashpee Wampanoag. I studied linguistics at MIT and Curriculum and Instruction at Boston College. I work for the Wôpanâak Language Reclamation Project and help create curriculum materials for a Wôpanâak immersion school.

huna mehé:ši. Katie degumdíPye? LéPi. hánalé:Iti gum t'ánu. Hayward šilu Lé?l Pida UC Berkeley šku:li Lépi. t'ánu hakwalulišge lášašé:si t'ida. dihamu Pánawi.

How are you? My name is Katie. I am of the Southern Washoe people. I am from Hayward, CA and I go to school at UC Berkeley. I study Native American history. I feel good.

This autoethnographic study centers on the critical role Indigenous graduate students play in language reclamation work. Each author is an Indigenous heritage language learner and current or recently-graduated doctoral student. Kari is Chickasaw and studies language reclamation and education at the University of Arizona. Nitana is Mashpee Wampanoag and specialized in culturally-based education at Boston College. Katie is Yerington Paiute and Washoe and studies Indigenous history at the University of California, Berkeley. We began by introducing ourselves in our languages as a means to honor, value, and respect each author's distinct voice and identity.

As Indigenous students, our efforts to ensure the continuity of our heritage languages are frequently overlooked within academic literature. Research often focuses on young first-language learners and elder fluent speakers, effectively ignoring "the roles of intermediate life stages" in the dynamics of language reclamation (Hornberger \& Swinehart, 2012, p. 36). Moreover, studies from the perspectives of speakers themselves are rare, and even rarer are studies centered on young people (McCarty, Romero-Little, Warhol, \& Zepeda, 2013). In the overwhelming absence of our voices within scholarly literature, our generation's pursuit of language and of higher education has been largely characterized by its unlikelihood of success.

Meek (2011) asserts that an "expectation of failure" surrounds younger generations of language learners who are characterized as inherently unable to acquire their heritage languages (p. 54). From surveys to census data, language shift is commonly illustrated through the ranking of individuals by age, which doubles as "a ranking by fluency, highlighting the decreasing fluency of younger 
generations" (Meek, 2011, p. 53). The danger of portraying young people in stark contrast to elder fluent speakers is the internalized notion that young people are inherently unable to speak their languages (Meek, 2011). Because of their supposed failure, younger generations may be viewed as allowing their languages to shift toward nonexistence.

With much research focused on factors contributing to Indigenous student attrition, "predictions of failure" also loom over our pursuit of higher education (Gilmore \& Smith, 2005, p.74; Shotton, Lowe, \& Waterman, 2013). For decades, the number of Indigenous doctorate recipients has hovered around 145 per year, representing only a fraction of a percent of the total degrees earned each year (Brayboy, Fann, Castagno, \& Solyom, 2012; Shotton, Lowe, \& Waterman, 2013). Indigenous graduate students face isolation, discrimination, and academic and cultural alienation, perpetuating a cycle of low graduation rates and continued underrepresentation (Brayboy et al., 2012).

As students and language learners, we resist expectations of failure in our efforts to ensure the continuity of our Indigenous heritage languages. Following our review of literature surrounding Indigenous language reclamation in higher education, we describe collaborative autoethnography as a research method. We then present personal vignettes and a discussion of the importance of access to Indigenous languages and the necessity of space at universities to engage in language reclamation. Ultimately, we share a view of higher education as a tool-though one that must be improved-that supports our contributions to language reclamation efforts in our communities.

\section{Literature Review}

While often used to describe the revival of languages which are no longer spoken (Grenoble \& Whaley, 2006), W. Y. Leonard (2011) defines language reclamation as a process that entails not only language acquisition, but "requires feeling and asserting the prerogative to learn and transmit the language...in a way that reflects the community's needs and values" (pp. 154-155). This conceptualization of language reclamation opens the possibility for higher education to be an authentic, culturally-appropriate, and even necessary means for younger generations to ensure the continuance of their languages. The acknowledgement of young people and students as vital contributors to language reclamation is further affirmed by a growing body of research which considers youth as both language learners and planners (e.g., McCarty et al., 2013; Wyman, 2012; Wyman, McCarty, \& Nicholas, 2014). Our review of the literature focuses on the potential of higher education to support language reclamation efforts. 


\section{Including Indigenous Languages in the Academy}

Learning and teaching Indigenous languages at universities differs greatly from learning and teaching other heritage and world languages (Hinton, 2011). Colonization and enduring and persistent pressures of assimilation have interrupted intergenerational transmission of Indigenous languages within families, leaving younger generations with less knowledge of their languages (Chew, 2015). University degree programs in Indigenous languages play a vital role in training these "missing generations" as second-language speakers and effective language teachers (Hinton, 2011, p. 307; Montgomery-Anderson, 2012; Warner, 1999). Currently, however, only three universities offer dedicated degree programs. $^{1}$

More common are programs that offer Indigenous language courses through a department that is not primarily focused on these languages (Montgomery-Anderson, 2012). These language courses do not typically lead to second-language fluency for students due to significant barriers impeding incorporation into university structures (Hinton, 2011; Morgan, 2005). For instance, institutional bureaucracy often places limits on community participation, an element vital to the success of language programs (Dementi-Leonard \& Gilmore, 1999; Morgan, 2005). Qualified instructors who speak an Indigenous language are rare, and gaining approval for and scheduling course offerings is challenging (Morgan, 2005). Community members who are not enrolled in a degree program may not be eligible for financial aid, making it impractical to assume the full cost of a university course. As a result, Indigenous language classes most often serve undergraduate and graduate students who have limited community involvement.

A lack of "indigenized" space within higher education exacerbates the challenges of including Indigenous language courses in the academy (Mihesuah \& Wilson, 2004). Universities privilege and validate Western knowledge (Brayboy \& Maughan, 2009; Roy \& Morgan, 2008), forcing Indigenous scholars to "seize" a context for "themselves, their communities, and...the linguistic and cultural knowledge they bring" (Gilmore, Smith, \& Kairaiuak, 2004, p. 281). Claiming and shaping Indigenous spaces can transform and benefit Indigenous communities and academia alike (Leonard \& Mercier, 2014; Montgomery-Anderson, 2012). Educating Indigenous and non-Indigenous students requires "establishment and expansion of safe Indigenous spaces within the Western institution that can both support student learning, and facilitate student contributions to insight and progression on issues affecting Indigenous peoples" (Leonard \& Mercier, 2014, p. 218).

Rather than focusing on language acquisition exclusively, Indigenous language instructors may focus more on the ability of their students to engage with Indigenous ontologies and epistemologies, which are tied to language (Leonard \& Mercier, 2014; B. Leonard, 2008; Roy \& Morgan, 2008). Roy and Morgan (2008) strive to teach Anishinaabemowin (Ojibwe language) in a way that is "consistent with Indigenous views about language use" (p. 241). By 
ensuring that the language always remains within its cultural context-rather than independent from other bodies of Anishinaabe knowledge-teaching language means teaching students to see the world through Anishinaabemowin (Roy \& Morgan, 2008). Because Indigenous knowledge cannot be fully understood when segmented (Berkes, 2012; Roy \& Morgan, 2008), language must also be central to any courses focused on Indigenous issues. B. Leonard (2008), for example, uses Deg Xinag (the language of the Deg Hit'an) oral tradition as a means to convey the importance of understanding Indigenous worldviews and educational paradigms to pre-service teachers at the University of Alaska-Fairbanks.

\section{Higher Education as a Critical Setting for Language Reclamation}

By prioritizing Indigenous languages, the university can function as a distinct setting for language reclamation that is both "separate from and supportive of the community whose language is undergoing revitalization" (Montgomery-Anderson, 2012, p.86). The university provides opportunities for scholars with shared goals of language reclamation to network locally, regionally, nationally, and internationally (Sumida Huaman \& Stokes, 2011). Both Gilmore (2013) and Leonard and Mercier (2014) discuss video-conferenced seminars in which university students from sites around the world engaged in dialogue about Indigenous languages and education. Significantly, these courses strengthened students' commitments to their communities and motivated them toward social transformation and social justice (Gilmore, 2013; Leonard \& Mercier, 2014).

While some students arrive on campus with aspirations of contributing to Indigenous communities, others develop these goals as they experience raised consciousness of language through their education (Smith, 2003; Lee, 2009). Lee (2009) explores how, within a postsecondary classroom centered on Indigenous language issues, students began to awaken to the inseparability of their heritage languages from their cultural identities. After becoming cognizant of language shift, students developed a new sense of agency and motivation "to intervene through their own research, language practices at home, and personal efforts to learn their heritage language" (Lee, 2009, p. 317).

In addition to supporting students' developing consciousness of language, the university may provide access to linguistic resources and offer linguistic training (baird, 2013; Baldwin, 2013; Kroupa, 2014). Both baird (Wampanoag) (2013) and Baldwin (Miami) (2013) pursued graduate degrees in linguistics in order to access linguistic materials in their languages and to restructure their community, family, and home lives around speaking these once sleeping heritage languages. Similarly, Kroupa (2014) enrolled in a doctoral program to access Arikara linguistic language materials housed on the campus. As part of his studies, he facilitated campus visits for other community members to engage with the materials to benefit language reclamation efforts in the community. These Indigenous scholars were not researching their languages at universities for the benefit of academia; instead, they went to universities to reclaim their languages and bring them home. In this way, while the university functions as a 
setting that supports language reclamation efforts, it cannot exist independently from communities.

\section{Indigenous Research and Collaborative Autoethnography}

Given the problematic ways in which Western research has been carried out in marginalized communities, Indigenous researchers seek culturallycongruent research methodologies that privilege Indigenous ways of knowing, being, and doing (Denzin, Lincoln, \& Smith, 2008; Smith, 1999; Wilson, 2009). This often means the ability to embrace our subjectivities and insider perspectives as Indigenous persons. As Meyer (2008) asserts, "Our rational minds, our inside thoughts, our subjective knowing are vital to how we experience and understand our world" (p. 227). Not Indigenous in origin, autoethnography aims to "describe and systematically analyze (graphy) personal experience (auto) in order to understand cultural experience (ethno)" (Ellis, Adams, \& Bochner, 2011, para. 1). In other words, autoethnographic research hinges on the subjectivity of researchers (Ellis, Adams, \& Bochner, 2011). For this reason, Bainbridge (2007) suggests that autoethnography can be adapted by Indigenous researchers as a means to work from an "epistemology of insiderness," in which Indigenous ways of knowing are both valid and prioritized, and to construct knowledge (p. 9).

Our own research journey began in fall 2012, when Kari initiated a pilot study of Indigenous graduate students' experiences studying their languages at universities. While this preliminary investigation produced rich data warranting further exploration, traditional ethnographic research methods, like interviews and surveys, were limiting. Participants did not have space to express their identities through their distinct languages and voices, nor could they contribute to the process of meaning-making. Seeking to continue the research using a more appropriate methodology, Kari invited Katie, a former classmate and participant in the pilot study, to begin a collaborative autoethnographic study. Nitana joined the following spring after meeting Kari at CUNY Graduate Center's Decolonizing Dialogues conference. As it turned out, Katie and Nitana already knew each other from previous work at the American Indian Child Resource Center in Oakland, California.

Chang, Ngunjiri, and Hernandez (2013) explained that for autoethnographic research to be conducted collaboratively, researchers must work individually and in community to collect, analyze, and interpret autobiographical materials. Our data collection and analysis unfolded over the course of a year. Each author began by contributing an initial written reflection guided by the following research questions:

1. What shaped our decisions to pursue language reclamation through graduate schools? 
2. What are the benefits and challenges of engaging in language reclamation in a university setting?

3. What are our goals after completing our programs?

At Pithouse-Morgan, Khau, Masinga, and van de Ruit's (2012) suggestion that letter-writing effectively facilitates self-reflexive and collaborative research, we responded to each other's reflections by letter using a cloud-based file sharing service. This correspondence served as a tool for the preliminary identification of emerging themes. Through continued communication via e-mail and comments on the manuscript, we also observed how, over time, our personal journeys continued to unfold and our reflections on the meaning of our experiences continued to develop.

In drafting the manuscript, each author reconstructed her initial writings and reflections based on the letters and other feedback as a vignette conveying a personal account of her experience. These vignettes served as important research tools because they "restructure[d] the complex dimensions of [their] subject[s] for the purpose of capturing, in brief portrayal, what has been learned over a period of time" (Ely, Vinz, Anzul, \& Downing, 1997, p. 70). Further, our vignettes functioned as a means both to collect and to present data (Blodgett, Schinke, Smith, Peltier, \& Pheasant, 2011). In the following sections, we present each author's vignette.

\section{Kari}

The story of language shift in my own family spans nearly two centuries. It begins in the late 1830s when the U.S. military forcibly expelled thousands of Chickasaws from their Southeastern homelands to Indian Territory (present-day Oklahoma). Among those displaced were my great-great-great-grandparents. Struggling to rebuild their lives and wanting more for their family, they sent their children to boarding schools for Chickasaw youth. In these schools, children were taught English and made ashamed of their Indigenous language. As the next generations in my family learned to speak English as their first and only language, our knowledge of Chikashshanompa' faded.

I first heard my heritage language spoken during a college internship with the Chickasaw Nation. On weekday mornings, I attended the language program's classes for staff. As I learned from our elder fluent speakers, the language captivated my soul. One of the first phrases I learned to say was, "Chikashsha saya [I am Chickasaw]." While I had spoken these words many times in English, my life was forever changed when I said them in the language of my ancestors. In that moment, I more fully recognized the importance of Chikashshanompa' to the continuance of Chickasaw culture and identity. I became inspired to continue learning my language, and to pursue language reclamation as an academic field and potential career path. 
After completing my undergraduate degree in Native American Studies, I applied to a master's program that offered the opportunity to study Chikashshanompa' both with an elder Chickasaw fluent speaker and with a linguist who had worked extensively on the language. Though the university was located far from the Chickasaw Nation, the program seemed ideal because I could continue my studies without fully sacrificing access to the language. Over the course of two semesters, the linguistics professor guided the class chapter by chapter through a Chickasaw grammar textbook, eliciting examples from the fluent speaker.

While I gained a strong understanding of Chikashshanompa' structures, I struggled with the ways in which language was stripped of cultural significance and instead portrayed as data that illuminated linguistic phenomena. One day in class, I recall the professor posing a question: Why would Chickasaws, who are in south-central Oklahoma, have a word for alligator? The professor's intention was to portray the word as an artifact reflecting our origins in the Southeast. When I raised my hand to offer that ancho'chaba' is also a clan animal with cultural significance, the professor replied that Chickasaws no longer remembered their clans. As the only Chickasaw student in class, my attempts to reposition my language from an academic context to a cultural context seemed to be met with resistance.

When I applied to my doctoral program, my priority was no longer finding a university that would "teach" me my language. Instead, I sought spaces which privileged the contributions of Indigenous peoples and provided opportunities to engage with other Indigenous scholars who were avidly pursuing their languages. For me, this space was the American Indian Language Development Institute (AILDI) at the University of Arizona.

In class, my instructors demonstrated language teaching methods and technology for language documentation. Assignments like building a website with interactive multimedia language activities pushed me to seek knowledge beyond the classroom and to consult my community. Teaching a language immersion lesson fully in Chikashshanompa' challenged me in my personal language learning efforts. By engaging in a space on campus which valued and privileged my identity and knowledge as an Indigenous person, I was empowered in my goals of language reclamation and motivated to continue my journey through higher education.

\section{Nitana}

I grew up in Mashpee, Massachusetts, in the home of my father's tribe, Mashpee Wampanoag. My mother's family is French-Canadian and, although I grew up speaking English in our house, I knew some French from her, as it was her first language. I did not know any Wôpanâôt8âô (Wampanoag language) until I was an adult. My father did not learn it as a child, and neither did his 
parents. Our language was unspoken for generations, captured only in written form in hundreds of Indigenous and non-Indigenous-written documents.

Because Wôpanâôt8âôk was not present for me growing up, it was certainly not something I intended to turn into a career. When I moved home after graduating from college, I began taking Wôpanâôt8âôk classes because I had access to them. I liked the structure of the workbook class I enrolled in because it catered to my learning style and I was good at it. After class one evening, my Wôpanâôt8âôk teacher approached me with the idea of applying to a master's program in linguistics at the Massachusetts Institute of Technology (MIT) to study Wôpanâôt8âôk. At the time, she was the only Wôpanâôt8âôk teacher and had gained much of her knowledge of the language through her work at MIT. She said that she had few other students who had caught on as quickly as I had to the language. With my bachelor's degree already behind me and her recommendation, she thought I would most certainly be accepted. She said that to continue to move forward the Wôpanâak Language Reclamation Project needed more speakers and teachers.

At that time, I think the idea of a master's degree at MIT excited me more than the work itself. I applied within the next few weeks and found out the following spring that I had been accepted. I spent the next two years taking some linguistics classes but mostly working with my advisor. Using written documents and previous linguistic work, he tutored me in the grammatical structures that had already been studied and gave me other structures to research and attempt to figure out myself. By the end of my program, I had a solid foundation in the grammatical structure of Wôpanâôt8âôk that I could use to teach other Wampanoag community members. Still, much of what I knew of Wôpanâôt8âôk at that time was tied to university learning and academic research skills.

Following graduation, I accepted a position in California at an after-school program for urban Indigenous youth. Working with the youth-many of whom were from tribes outside of California and did not have access to their cultures and languages - helped me to realize how fortunate I was to know my community and for my community to know me. It was then that I decided to pursue a doctorate in education and work toward the development of a culturally-based curriculum for Wampanoag students.

I earned my degree at Boston College in Curriculum and Instruction, a program I chose because of its proximity to my home and a fellowship that allowed me flexibility while in school. The freedom to study off-campus meant that I could do language and education work in my community and develop my goals alongside community goals. Now that I have graduated, I hope that my work will lead to a Wôpanâôt8âôk immersion school that will become a model and contribute to the successful, useful, and positive work done in other Indigenous communities. In this way, the relationship between language work in my community and academia is inevitable right now. 


\section{Katie}

I was born and raised in the San Francisco Bay Area-many miles, if not worlds, away from my family's ancestral lands. Despite the distance, my family fostered my connection to my heritage and love for languages. While English is my first language, I was regularly exposed to Portuguese, I had some knowledge of Italian, and my paternal grandparents both fluently spoke their heritage languages of Wa:šiw (Washoe) and Numu yadua (Northern Paiute).

As an undergraduate at UC Berkeley, I enrolled in Portuguese language classes to learn my maternal heritage language. In my junior year, I traveled to Portugal and met distant relatives. As we said our goodbyes, my grandmother's cousin placed her palm next to mine. She pointed to my veins and said, "O mesmo sangue, o mesmo sangue [The same blood that runs through your veins runs through mine]." At that moment, I came to understand the strength of language - that even thousands of miles away I was connected to a home. Perhaps this phenomenon is more significant for endangered heritage languages.

My grandfather, a native Wa:šiw speaker, taught my sisters and me Wa:šiw words when we were children. Our daily lessons covered body parts and kinship words, though my Paiute grandmother regularly insisted on Numu yadua terms. Our grandparent's language lessons did not hide the fact that Wa:šiw and Numu yadua are both endangered languages. In fact, my grandfather knew this well, and before he passed away he recorded as many Wa:šiw words and phrases he could. From a young age I knew that "saving" languages or reversing language shift required action.

In my young adulthood, I recollected my days of reciting Wa:šiw and Numu yadua with my grandparents and wanted to rekindle those words that shaped me. At the start of my master's program, I had the opportunity to take an American Indian linguistics course which allowed me to choose Wa:šiw as a language of focus. With a Wa:šiw grammar in hand, I began on a path that has led me towards a personal and scholarly journey with the language. For my master's thesis, I created a historiography of Wa:šiw reclamation efforts, articulating community members' language ideologies and their hopes for the future of Wa:šiw. My degree program provided me with essential tools to develop my language learning skills and community research methods. And through my research, I felt a stronger connection to my community - that home, many miles away.

Returning to UC Berkeley as a doctoral student, I was not immediately able to continue my study of Wa:šiw. Because my research shifted towards critiquing the generational effects of American Indian assimilation programs, I felt I had to choose between my research and my language. In fact, I often felt that 
learning Wa:šiw required a move to Nevada to take up a Master-Apprentice ${ }^{2}$ Language Learning program. However, in the spring of 2015, everything changed. I had the opportunity to take the first ever Wa:šiw course on campus.

On my first day of class, I was nervous and thrilled to be able to hear Wa:šiw at my school. It was terribly moving to walk through campus and step into my Wa:šiw class, just like any other class or seminar. Though I was the only Indigenous student in my class of 30, I did not feel isolated in my daily language exploration. Instead I felt empowered because my campus finally reflected what mattered to me. As someone who lives hundreds of miles away from my community, I felt even closer.

My passion for learning critical Indigenous community history and Indigenous heritage languages has inspired me to teach at the university level and empower students from all communities. Though my research has grown in new directions, language is at the heart. It nurtures that home I feel when I hear and speak the words of my ancestors. In the same vein of "o mesmo sangue," I follow the words-the same words that ran from your breath run through mine.

\section{Discussion}

As young adults, we each developed increased consciousness of the role of our languages in our lives, communities, and futures (Lee, 2009). Moving away from her community allowed Nitana to more fully recognize her language as a gift, one which called her home to support community language reclamation work professionally and through doctoral study. Contrastingly, Kari developed consciousness of language by returning and reconnecting to the Chickasaw community. Learning to say "Chikashsha saya [I am Chickasaw]" deepened her sense of cultural identity and motivated her to further pursue language reclamation through her studies and potential career. For Katie, reconnecting to a non-Indigenous heritage language and community inspired her commitment to Wa:šiw. Honoring her grandfather's work to save Wa:šiw, she prioritized the language in her academic research.

We committed ourselves to language reclamation work in order to ensure that language will be part of not only our futures, but the futures of our communities. In her vignette, Katie reflects on higher education as tool for language reclamation. Through our degree programs, we gained knowledge of our languages and their linguistic structures, as well as research skills and credentials vital to our language work. At the same time, we also recognize this tool's limitations. In discussing emerging themes from our data, we illuminate the challenges and benefits of accessing Indigenous languages from campus and claiming and creating space for language reclamation. 


\section{Accessing Indigenous Languages from Campus}

In our research process, we explored the significance of access to language along our language learning, educational, and professional trajectories. Responding to Katie's perception that learning Wa:šiw might require relocating to Nevada, Kari wrote:

When we go to school away from our communities, we are faced with a choice between learning in the community and learning at the university. It would be great if we could explore more in depth how we are navigating such decisions.

As we further considered the ways in which we endeavored to access language while in school, we saw themes of agency and persistence. From Kari's selection of a master's program offering Chickasaw linguistics courses to Nitana's diligence in studying from off-campus to Katie's thesis fieldwork on Wa:šiw, we actively and continually sought out our languages.

Though we did not rely on our institutions to provide access to language, Katie's vignette demonstrates how powerful it is for an Indigenous heritage language to be present on campus. For Katie, stepping into her Wa:šiw language class at Berkeley was "moving." On Monday, Wednesday, and Friday mornings, she had the ease of access to Wa:šiw. With each class she became more comfortable speaking and listening to Wa:šiw and its song. While Katie considers this class a blessing, she also reflects that, because language is inherently connected to land, culture, and people, it cannot fully replace the experience of learning language within the community

Although access to Indigenous languages on campus can positively impact language reclamation work (Hinton, 2011; Montgomery-Anderson, 2012), oppressive colonial legacies of universities, including inequity of power between Indigenous and non-Indigenous voices, can also disempower students (Gilmore \& Smith, 2005; Warner, 1999). As the only heritage language learners in their language courses, Katie and Kari both felt responsibility to represent their communities. In correspondence with Kari about the manuscript, Katie reflected that while she tried to speak up in class, she also chose not to "out" herself as Washoe to her classmates.

In contrast, Kari's status as the only Chickasaw student in her linguistics course was very much a part of the class dynamic. The professor would call upon her to do things like sing Chikashshanompa' songs with the elder language speaker present in class. In this way, Chickasaw culture was only welcome in the classroom on the professor's terms (Warner, 1999). When Kari as a student initiated dialogue connecting her language to cultural context, her comments were largely dismissed. The benefits of offering Indigenous language courses are severely impeded when classroom environments do not respect and value Indigenous voices and cultures. 
While our universities have imparted valuable skills that enable us as more effective language learners and teachers, they have done little to connect us to our communities in a way that is real or directly helpful to them. After completing her degree at MIT, Nitana's knowledge of Wôpanâot8âôk was tied to university learning and academic research skills. In early reflections shared with the group, Nitana wrote:

Despite teaching classes to Wampanoag tribal members, I did not make a true connection between learning the language in an academic setting and its impact on the community.

When she began her doctoral program, however, her priorities had shifted from researching her language to contributing to the establishment of a language immersion school. To this end, Nitana sought flexibility to pursue her degree while working in her community. Nitana's account affirms that language learning requires not just academic study, but opportunity to return knowledge gained at the university to the community (baird, 2013; Baldwin, 2013).

\section{Claiming and Creating Space for Language Reclamation}

While access to language supports the pursuit of language reclamation through higher education, also necessary are spaces to construct, deconstruct, and reconstruct meaning and understanding in relation to Indigenous languages and knowledge systems (Leonard \& Mercier, 2014). Because Indigenous voices tend to be undervalued and marginalized on campuses, such space is a rarity (Gilmore \& Smith, 2005; Gilmore, Smith, \& Kairaiuak, 2004). As Nitana reflects, the university was not supportive of her inclusion of Wampanoag knowledge in the academy in the same way it expected her to use her academic knowledge in her community. Without the support of our universities, we as students are left to "carve an open space, or sphere of freedom to voice [our] subaltern and subjugated knowledge" (Gilmore \& Smith, 2005, p. 69).

During our research, Katie took initiative to claim and create a space for collaboration between her university and her community. Through her Washoe language course, Katie recognized the need to include Washoe community members involved in language work not as just guest lecturers, but as collaborators. To this end, Katie organized a panel of elders, language teachers, and Washoe historians to engage with campus resources and dialogue with the campus community. Katie reflected in correspondence to the group: "The panel served as a means to connect both the academy and community-building a bridge between two groups that are less often in direct collaboration."

Though Indigenous students may seize their own spaces (Gilmore \& Smith, 2005), universities are not relinquished from responsibility to proactively support spaces which privilege Indigenous languages and knowledge (Leonard \& Mercier, 2014). For Kari, even more important than access to language has been space on campus to explore and develop her identity as an Indigenous scholar committed to language. Designing teaching materials and lessons as part of her 
AILDI coursework allowed Kari to (re)turn to and explore Chickasaw cultural models and then to rearticulate them into contemporary frameworks, such as a classroom or a website.

Safe, indigenized spaces to engage with our languages and knowledges (Leonard \& Mercier, 2014) support not only our language learning and educational trajectories, but also our professional trajectories. Katie envisions herself studying Wa:šiw while also documenting community histories through a career in academia and in the professoriate. At the root of Katie's goals is the desire to see Indigenous students become empowered through learning and appreciating their own languages, cultures, and histories. Her progress toward this goal has been inspired and enabled by the power of her Wa:šiw class, as well as opportunities and funding to conduct research in collaboration with her community.

Kari strives to return to the Chickasaw Nation and work to support and strengthen language programming. Vital to her progress through her degree program has been mentorship from faculty advocates who support and understand her goals, and who model what it means to engage in language reclamation efforts from within academia. A continual challenge, however, is staying committed to language learning while going to school far from the Chickasaw Nation.

Nitana, who also plans a career with her community, also found that the university has not offered adequate space on campus to maintain a commitment to language learning. In her letter to Kari, she reflected:

It's interesting to think of language revitalization as a "potential" career. I've come to find it necessary in my life in order to truly maintain [my language learning].... Sitting down 6 hours a day, 5 days a week [at work in my community] and focusing on language allows me to progress. I sometimes don't know how others learn when they don't have that same opportunity!

Enabled by the flexibility of living off-campus, Nitana found space within her community to grow her personal academic and professional goals alongside community goals. Significantly, because Nitana speaks Wôpanâôt8âôk and has a credential that satisfies state requirements for school administration, she is uniquely equipped to direct curricula for her community.

\section{Conclusion}

Our collaborative autoethnographic study explored our decisions, as Indigenous heritage language learners, to pursue language reclamation in graduate school, the benefits and challenges of engaging in language reclamation in a university setting, and our post-graduation goals. We each experienced an awakening to the importance of our languages (Lee, 2009), which motivated our enrollment in doctoral programs. With both cultural 
knowledge and advanced degrees, we desired to significantly impact language reclamation work in our communities.

Our data collection and analysis revealed challenges and benefits to accessing Indigenous languages from campus and claiming and creating space for language reclamation. While the importance of access and space has been noted in the literature (Hinton, 2011; Leonard \& Mercier, 2014; MontgomeryAnderson, 2012; Warner, 1999), our study uniquely portrays personal perspectives of Indigenous students and language learners. Significantly, our research points to the potential for higher education to be shaped as a more effective tool for Indigenous graduate students engaged in language reclamation.

Our study makes apparent the need for access to Indigenous language, whether through dedicated courses taught in collaboration with community or flexible degree programs that enable students to study from their communities. Access must be complemented by space which privileges Indigenous knowledge and languages, and allows Indigenous students to develop as scholars and professionals committed to language reclamation work. In this way, our language learning, educational, and professional trajectories can unfold simultaneously, positioning us to as unique contributors to language reclamation work.

Whereas we began this article by considering expectations of failure imposed on us as students and language learners, we conclude with our own expectation that we will be successful as language learners and as students. As part of an emerging generation of Indigenous scholars engaged in language reclamation, we will ensure the continuity of our Indigenous heritage languages. Language reclamation requires the commitment of many, including the academy. With sustained commitment from Indigenous communities and Indigenous scholars, our hope is that the academy will continue to make available resources for learning Indigenous languages, to provide space for students to (re)claim and (re)construct Indigenous knowledge, and to ensure opportunity for Indigenous scholars.

\section{Notes}

1. The three universities offering degree programs in Indigenous languages are: Northeastern State University (Cherokee); University of Hawai'i (Hawaiian); and University of Alaska (Iñupiaq and Yup'ik)

2. Master-Apprentice is a language learning model in which one-on-one teams comprised of a language learner and a fluent speaker complete a predetermined number of oral language immersion hours, usually over the course of a year (see Hinton, Vera, \& Steele, 2002) 


\section{References}

Bainbridge, R. (2007). Autoethnography in Indigenous research contexts: The value of inner knowing. Journal of Australian Indigenous Issues, 10(2), 5464.

baird, j. I. d. (2013). How did this happen to my language? In L. Hinton (Ed.), Bringing our languages home: Language revitalization for families (pp. 1930). Berkeley, CA: Heyday.

Baldwin, D. (2013). myaamiaataweenki oowaaha: Miami spoken here. In L. Hinton (Ed.), Bringing our languages home: Language revitalization for families (pp. 3-18). Berkeley, CA: Heyday.

Berkes, F. (2012). Sacred ecology (3rd ed.). New York, NY: Routledge.

Blodgett, A. T., Schinke, R. J., Smith, B., Peltier, D., \& Pheasant, C. (2011). In Indigenous words: Exploring vignettes as a narrative strategy for presenting the research voices of Aboriginal community members. Qualitative Inquiry, 17(6), 522-533.

Brayboy, B. M. J., Fann, A. J., Castagno, A. E., \& Solyom, J. A. (2012). Postsecondary education for American Indian and Alaska Natives: Higher education for nation building and self-determination. ASHE Higher Education Report, 37(5).

Brayboy, B. M. J., \& Maughan E. (2009) Indigenous knowledges and the story of the bean. Harvard Educational Review, 79(1), 1-21.

Chang, H., Ngunjiri, F. W., \& Hernandez, K. C. (2013). Collaborative autoethnography. Walnut Creek, CA: Left Coast Press.

Chew, K. A. B. (2015). Family at the heart of Chickasaw language reclamation. American Indian Quarterly, 39(2), 154-179.

Dementi-Leonard, B., \& Gilmore, P. (1999). Language revitalization and identity in social context: A community-based Athabascan language preservation project in western interior Alaska. Anthropology and Education Quarterly, 30(1), 37-55.

Denzin, N. K., Lincoln, Y. S., Smith, L. T. (2008). Handbook of critical and Indigenous methodologies. Thousand Oaks, CA: Sage.

Ellis, C., Adams, T. E., \& Bochner, A. P. (2011). Autoethnography: An overview. Forum Qualitative Sozialforschung, 12(1). Retrieved from http://nbnresolving.de/urn:nbn:de:0114-fqs1101108

Ely, M., Vinz, R., Anzul, M., \& Downing, M. (1997). On writing qualitative research: Living by words. Washington, DC: The Falmer Press.

Gilmore, P. (2013, November). Knowledge production in Indigenous scholarship: Fostering relationships, reciprocity, responsibility and respect through 
cross-institutional engagements. Paper presented at the meeting of the American Anthropological Association, Chicago, IL.

Gilmore, P., \& Smith, D. M. (2005). Seizing academic power: Indigenous subaltern voices, metaliteracy, and counternarratives in higher education. In T. L. McCarty (Ed.), Language, literacy, and power in schooling (pp. 6788). Mahwah, NJ: Lawrence Erlbaum.

Gilmore, P., Smith, D. M., \& Kairaiuak, A. P. (2004) Resisting diversity: An Alaskan case of institutional struggle. In M. Fine, L. Weis, L. Powell Pruitt, \& A. Burns (Eds.), Off white: Readings on power, privilege, and resistance (pp. 273-283). New York, NY: Routledge.

Grenoble, L. A., \& Whaley, L. J. (2006). Saving languages: An introduction to language revitalization. Cambridge, UK: Cambridge University Press.

Hinton, L. (2011). Language revitalization and language pedagogy: New teaching and learning strategies. Language and Education, 25(4), 307-318.

Hinton, L., with Vera, M., \& Steele, N. (2002). How to keep your language alive: A commonsense approach to one-on-one language learning. Berkeley, CA: Heyday Books.

Hornberger, N. H., \& Swinehart K. F. (2012). Not just situaciones de la vida: Professionalization and Indigenous language revitalization in the Andes. International Multilingual Research Journal, 6(1), 35-49.

Kroupa, K. T. (2014). Efforts of the Re-evolution: Revitalizing Arikara language in an endangered language context. In L. T. Wyman, T. L. McCarty, \& S. E. Nicholas (Eds.), Indigenous youth and bi/multilingualism: Language identity, ideology, and practice in dynamic cultural worlds (pp. 168-186). New York, NY: Routledge.

Lee, T. S. (2009). Language, identity, and power: Navajo and Pueblo young adults' perspectives and experiences with competing language ideologies. Journal of Language, Identity, and Education, 8(5), 307-320.

Leonard, B. (2008). Mediating Athabascan Oral Traditions in Postsecondary Classrooms. International Journal of Multicultural Education, 10(2). Retrieved from http://ijme-journal.org/index.php/ijme/article/view/126/227

Leonard, B., \& Mercier, O. (2014). Shaping Indigenous spaces in higher education: An international virtual exchange on Indigenous knowledge (Alaska and Aotearoa). Canadian Journal of Native Education, 37(1), 218238.

Leonard, W. Y. (2011). Challenging "extinction" through modern Miami language practices. American Indian Culture and Research Journal, 35(2), 135-160.

McCarty, T. L., with Romero-Little, M. E., Warhol, L. \& Zepeda, O. (2013). Language in the lives of Indigenous youth. In T. L. McCarty (Ed.), Language planning and policy in Native America: History, theory, praxis (pp. 156-182). Tonawanda, NY: Multilingual Matters. 
Meek, B. A. (2011). Failing American Indian languages. American Indian Culture and Research Journal, 35(2), 43-60.

Meyer, M.A. (2008). Hawaiian epistemology and the triangulation of meaning. In N. K. Denzin, Y. S. Lincoln, \& L. T. Smith (Eds.), Handbook of critical and Indigenous methodologies (pp. 217-232). Thousand Oaks, CA: Sage.

Mihesuah, D. A., \& Wilson, A. C. (2004). Indigenizing the academy: Transforming scholarship and empowering communities. Lincoln, NE: University of Nebraska Press.

Montgomery-Anderson, B. (2012). Creating partnerships between the Indigenous language community and the university: The experience of the Cherokee education degree program. In S. Rivera-Mills \& J. A. Trujillo (Eds.), Building Communities and Making Connections (pp. 81-97). New Castle upon Tyne, UK: Cambridge Scholars Publishing.

Morgan, M. J. (2005). Redefining the Ojibwe classroom: Indigenous language programs within large research universities. Anthropology and Education Quarterly, 36(1), 96-103.

Pithouse-Morgan, K., Khau, M., Masinga, L., \& van de Ruit, C. (2012). Letters to those who dare feel: Using reflective letter-writing to explore the emotionality of research. International Journal of Qualitative Methods 11(1), 40-57.

Roy, H., \& Morgan, M. J. (2008). Indigenous languages and research universities: Reconciling worldviews and ideologies. Canadian Journal of Native Education, 31(1), 232-247.

Shotton, H. J., Lowe, S. C., \& Waterman, S. J. (Eds.). (2013). Beyond the asterisk: Understanding Native students in higher education. Sterling, VA: Stylus Publishing.

Smith, G. H. (2003, October). Indigenous struggle for the transformation of education and schooling. Keynote Address to the Alaskan Federation of Natives (AFN) Convention, Anchorage, AK.

Smith, L. T. (1999). Decolonizing methodologies: Research and Indigenous peoples. New York, NY: Zed Books.

Sumida Huaman, E., \& Stokes, P. (2011). Indigenous language revitalization and new media: Postsecondary students as innovators. Global Media Journal (11)18. Retrieved from http://lass.purduecal.edu/cca/gmj/sp11/gmj-sp11article3.htm

Warner, S. L. N. (1999). Kuleana: The right, responsibility, and authority of Indigenous peoples to speak and make decisions for themselves in language and cultural revitalization. Anthropology and Education Quarterly, 30(1), 68-93.

Wilson, S. (2009). Research is ceremony: Indigenous research methods. Winnipeg, MB: Fernwood Publishing. 
Wyman, L. T. (2012). Youth culture, language endangerment and linguistic survivance. Bristol, UK: Multilingual Matters.

Wyman, L. T., McCarty, T. L., \& Nicholas, S. E. (Eds.). (2014). Indigenous youth and bi/multilingualism: Language identity, ideology, and practice in dynamic cultural worlds. New York, NY: Routledge.

\section{Author Contact}

Kari A. B. Chew: karichew@email.arizona.edu

University of Arizona, College of Education, 1430 E. Second St., Tucson, AZ

85721, USA

Nitana Hicks Greendeer: nhicks@wlrp.org

Boston College, Lynch School of Education, 140 Commonwealth Ave., Chestnut

Hill, MA 02467, USA

Caitlin Keliiaa: ckeliiaa@berkeley.edu

University of California, Berkeley, Ethnic Studies Department, 506 Barrows Hall

\#2570, Berkeley, CA 94720, US 